\title{
Pesticide Residues in The Formoso River: A Threat To Biodiversity In The Cerrado of The Tocantins State, Brazil
}

Patrícia Martins Guarda ( $\sim$ patriciaguarda@uft.edu.br)

Universidade Federal do Tocantins https://orcid.org/0000-0003-0937-6779

Larissa da S. Gualberto

UFT: Universidade Federal do Tocantins

Danylo B. Mendes

UFT: Universidade Federal do Tocantins

Emerson Adriano Guarda

UFT: Universidade Federal do Tocantins

José Expedito C. da Silva

UFAL: Universidade Federal de Alagoas

\section{Research Article}

Keywords: pesticides, water, soil, sediment, Tocantins

Posted Date: February 16th, 2022

DOI: https://doi.org/10.21203/rs.3.rs-1343982/v1

License: (9) This work is licensed under a Creative Commons Attribution 4.0 International License. Read Full License 
PESTICIDE RESIDUES IN THE FORMOSO RIVER: A THREAT TO BIODIVERSITY IN THE CERRADO OF THE TOCANTINS STATE, BRAZIL

\author{
Patricia M. Guarda ${ }^{\mathrm{a} 1}$, Larissa da S. Gualberto ${ }^{\mathrm{a} 2}$, Danylo B. Mendes ${ }^{\mathrm{a} 3}$, Emerson A. Guarda ${ }^{\mathrm{a} 4}$ e José $^{\text {Eme }}$ \\ E. C. da Silva ${ }^{a 5}$ \\ ${ }^{a 1}$ Environmental Chemistry and Biofuels Laboratory, Federal University of Tocantins, 77001-090 Palmas \\ - TO, Brazil. corresponding author : patriciaguarda@uft.edu.br (orcid.org/0000-0003-0937-6779) ${ }^{\mathrm{a} 1}$, \\ larissagualberto.eng@gmail.com (orcid.org/0000-0002-7335-1771) a2 , danylo@uft.edu.br (orcid.org/0000- \\ 0002-2115-9796) ${ }^{\mathrm{a} 3}$, emersonprof@uft.edu.br (orcid.org/0000-0003-0227-3881) ${ }^{\mathrm{a} 4}$, \\ jose.silva@penedo.ufal.br (orcid.org/0000-0002-8776-389X) a $^{\mathrm{a} 5}$.
}

\begin{abstract}
The biodiversity of the Cerrado has been threatened by the increase in agricultural production in the state of Tocantins and by the increased use of pesticides. This region of Formoso do Araguaia, it is home to around 1,825 indigenous people and is one of the largest indigenous territories in the state of Tocantins This work investigates the levels of pesticide residues in different environmental compartments (soil, sediment and water samples) of the Formoso River in the state of Tocantins, Brazil. The presence of pesticides of the imidazolinones and strobirulins classes by UHPLC-MS/MS were analyzed from April 2018 to February 2019, which helped in an evaluation of the impacts of pesticides on the biodiversity of the place of study. After analysis, five active principles (azoxystrobin, fenamidone, imazethapyr, tricyclazole, and trifloxystrobin) were detected in the water matrix, two active principles (azoxystrobin and tricyclazole) in the soil matrix, but no active principle was detected in the sediment matrix. In the region of the Parque do Araguaia Indigenous Lands, people who use this water for cultivation, hygiene and food, which is worrying, are exposed to these substances.
\end{abstract}

KEYWORDS: pesticides; water; soil; sediment; Tocantins

\title{
Introduction
}

The largest biodiversity on the planet is found in Brazil in six different biomes, namely the Amazon, Cerrado, Atlantic Forest, Caatinga, Pantanal, and Pampa (Magalhães, 2018). Each biome has different physical, chemical and biological characteristics according to soil, climate, vegetation, animals, and microorganisms. Biodiversity loss is one of the biggest threats to the global ecosystem, as it can change the functioning of biological processes, agricultural productivity and environmental sustainability (MONTEIRO, 2007). In this context, the conservation of these Brazilian biomes has been a matter of concern due to extinction threats mainly influenced by agricultural deforestation (Abujaile et al., 2011).

The growth of agriculture in the Cerrado of Tocantins also increases the amount of foreign substances added to the environment, which reach the environmental compartments of water bodies in 
different ways. Such increase is not only in the amount used, but also in the variety of substances used for different types of crops. This poses a threat to all diversity still existing in these aquatic environments.

Some aspects have caused water quality problems in the main Tocantins watersheds, such as the lack of efficient planning of use of water resources, the disorderly advance of agricultural frontiers, industrial, urban and agricultural pollution, climate variability such as droughts, among others (SEPLAN, 2016). In addition, changes in the Cerrado resulting from land use due to agrarian development, characterized by the conversion of native areas into pastures and agricultural areas, may be affecting the different communities within this biome (Mesquita, 2011).

Biodiversity is supported by species diversity, genetic diversity and ecosystem diversity. This triad has been affected by physical pressures, degradation or loss of habitats, chemical pressures, the action of contaminants in the environment, biological pressures, introduction of exogenous substances, and/or trophic chain disruption, and elimination of key species in ecological communities (Alho, 2005). The frequency of exposure also affects the toxicity of chemical compounds. An acute exposure to a single concentration may result in an immediate adverse effect on an organism; two successive cumulative exposures equal to a single acute exposure may have little or no effects due to organism metabolism between exposures or organism acclimatization to the compound (Rand and Petrocelli, 1985).

The biological cycle of a pesticide includes bioconcentration in plants and animals, and incorporation into the food chain is by water or soil (Oliveira and Silva, 2013). Bioaccumulation is the process by which living beings absorb and retain substances in their organisms. Biomagnification is the increase in the concentration of a substance in organisms as the trophic level increases (Isherwood, 2000). This bioamplification of the concentration in the body tissues of organisms may reach concentrations above those of the environment in which these organisms inhabit (De Geronimo et al., 2014).

Much of the territory of the state of Tocantins is located within the Cerrado biome (Carvalho et al., 2018). This biome comprises a set of ecosystems in Central Brazil. It has a large biodiversity of endemic species (Mesquita, 2011) and is the habitat of 160,000 species of animals, plants and fungi (Coba, 2012). However, the expansion of MATOPIBA (Maranhão, Tocantins, Piauí, and Bahia) has decreased the native area of this biome and increased the conversion of natural into agricultural areas (Silva, 2012). Biodiversity is greatly affected by human activity and the relationship between it and the functioning of the ecosystem has become the focus of studies in recent decades (Zhang et al., 2017).

Only with scientific knowledge about the Cerrado can the reduction, loss, change or degradation of habitats strongly influenced by anthropic actions be avoided. These studies can propose actions that ensure the preservation of the biodiversity of this biome (Azevedo et al., 2016).

In the region of Formoso do Araguaia, it is home to around 1,825 indigenous people and is one of the largest indigenous territories in the state of Tocantins. According to Mattos et al. (2013), the region of the Indigenous Lands of Parque do Araguaia, shelter the Javaé, Karajá and Avá Canoeiro peoples who use this water for cultivation, hygiene and food, which is worrying.

Considering the expansion of agriculture in the Legal Amazon region, growth of the planted area in Tocantins and in the Rio Formoso Agricultural Project and the increase in the use of pesticides, which accompanies the increase in the planted area, this study on the determination of pesticides of the classes was carried out of imidazolinones and strobirulins in environmental compartments of Rio Formoso to verify 
the influence of the agricultural project on the contamination of this environment.

\section{Materials dnd Methods}

The samples were collected at seven points of the Formoso River within the Rio Formoso Agricultural Project in Formoso do Araguaia, TO, Brazil. The choice of points focused on verifying the influence of the project on river contamination. A point was selected on the river before it passed the agricultural project (P1), five points along the project (P2 to $\mathrm{P} 6)$, and one point after the project (P7), as shown in Figure 1. The four campaigns were held in April (Campaign 1-C1) in the rainy season, July (Campaign 2- C2), October (Campaign 3- C3), conducted in the dry season of 2018, and February 2019 (Campaign 4- C4) in the rainy season.

The rainfall conditions on the days of collection were $11.4 \mathrm{~mm}$ in $\mathrm{C} 1,0 \mathrm{~mm}$ in $\mathrm{C} 2$ and $\mathrm{C} 3$, and $0.6 \mathrm{~mm}$ in $\mathrm{C} 4$. The depth of the river reflects these climatic conditions. Only two points (P1 and P5) have depth data, as they have real-time monitoring. In $\mathrm{C} 1,830 \mathrm{~cm}$ in P1 and $650 \mathrm{~cm}$ in P5; in $\mathrm{C} 2,275 \mathrm{~cm}$ in P1 and $183 \mathrm{~cm}$ in $\mathrm{P} 5$; in $\mathrm{C} 3,233 \mathrm{~cm}$ in $\mathrm{P} 1$ and $158 \mathrm{~cm}$ in $\mathrm{P} 5$; and in $\mathrm{C} 4,413 \mathrm{~cm}$ in $\mathrm{P} 1$ and $249 \mathrm{~cm}$ in $\mathrm{P} 5$ (SEMARH, 2017; SEMARH, 2018a; SEMARH, 2018b; SEMARH, 2018c; SEMARH, 2018d).

The collection period for each campaign lasted 48 hours. The collection was carried out by boat following the same collection time in each point. The rainy season sampling was carried out without strong rains.

Although it is known that the active ingredients selected in this work may not be those most used in the studied region, the selection of pesticides was due to data availability, since an inventory of substances used was not carried out in the studied region. Data on the use and sales of products in the region were not obtained from regulatory agencies. The state of Tocantins, as many states in Brazil, does not have a database on substances used.

Pesticides were analyzed by a UHPLC-MS/MS from Waters (USA), namely imazamoxy, imazapyr, imazapic, imazethapyr, imazaquin, phenimidone, azoxystrobinam methyl cremoxim, piraclostrobin, trifloxystribin, and tricyclazole (Kemmerich, 2017). For the analysis of the pesticides, soil, sediment and water, samples were collected and stored according to Filizola et al. (2016) and CETESB (2011) and analyzed within 48 hours after collection.

For soil samples, approximately $2 \mathrm{~kg}$ of the surface layer were collected up to $20 \mathrm{~cm}$ deep, 5 to 10 $\mathrm{m}$ from the riverbank, in a composite sampling. For sediment samples, approximately $2 \mathrm{~kg}$ of the surface layer were collected 5 to $10 \mathrm{~m}$ from the riverbank, in a composite sampling, with a modified Petersen stainless steel collector. Water samples were collected from the surface of the water body 5 to $10 \mathrm{~m}$ from the riverbank due to a large difference in river depth at different collection times. Simple sampling was performed, and samples were packed in 500-mL amber flasks.

Fig 1 Image with sample area and collection points 


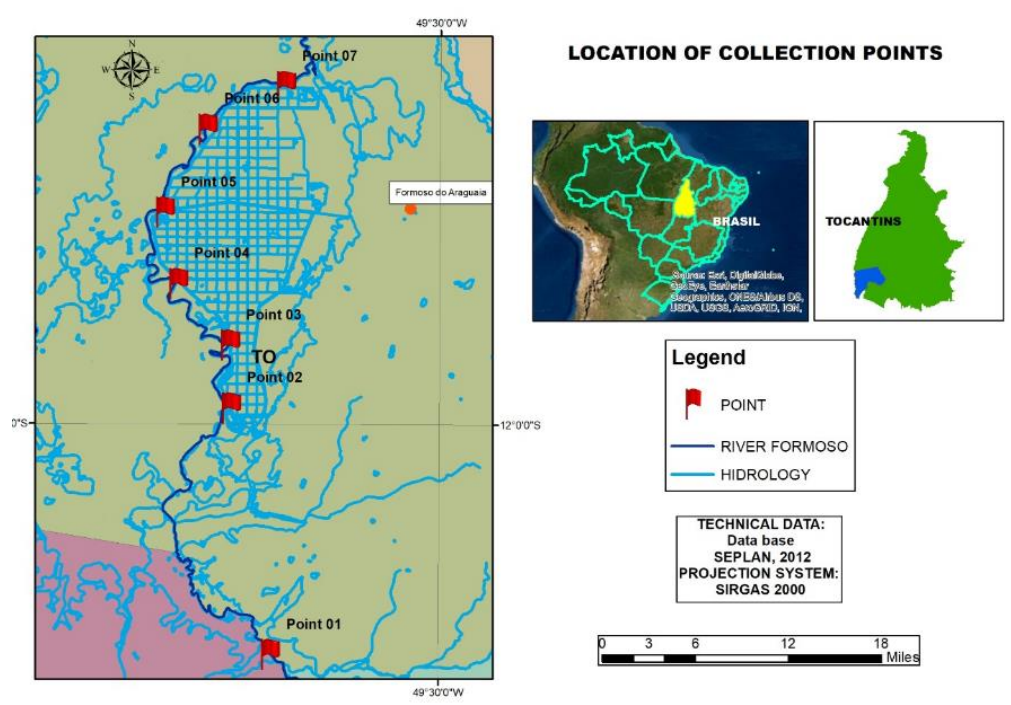

Source: SEPLAN, 2012.

Sediment and soil samples were prepared for extraction analysis using the modified QuEChERS method. The method used acidified acetonitrile as extraction solvent; for the partition step, the salts used were magnesium sulfate and sodium chloride. The extracts were cleaned by dispersive solid phase extraction (d-SPE). For the d-SPE step, magnesium sulfate and octadecylsilane (C18) and secondary primary amine (PSA) solvents were used. The extracts were then stirred, centrifuged and filtered. Prior to UHPLC-MS/MS analysis, samples were diluted five times in ultrapure water (Prestes, 2009).

For pesticide analysis in water samples, a solid phase extraction (SPE) was performed. For the SPE procedure, Oasis ${ }^{\circledR}$ HLB cartridges were used, $100 \mathrm{~mL}$ of sample were percolated and eluted with the acidified mixture $\mathrm{MeOH}: \mathrm{MeCN}(1: 1, \mathrm{v} / \mathrm{v})$. Before chromatographic injection, samples were diluted twice in ultrapure water (Donato, 2015).

The analyses were performed by ultra-high performance liquid chromatography coupled with a UHPLC-MS/MS serial mass spectrometry equipped with liquid chromatograph; triple quadrupole MS detector, Xevo TQ; electrospray ionization interface/source; peak nitrogen generator; solvent controller system (binary pump system) for high pressure gradient operation; Acquity UPLC ${ }^{\circledR}$ BEH C18 analytical column $(50 \times 2.1 \mathrm{~mm}, 1.7 \mu \mathrm{m})$ manufactured by Waters (USA); and data acquisition system using the MassLynx 4.1 software (Waters, USA). The monitoring of selected reactions was used for quantification and identification of analytes. The mobile phase was (A) water: methanol (98:2, v/v) and (B) methanol, both containing $5 \mathrm{mmol} \mathrm{L}^{-1}$ of ammonium formate and $0.1 \%$ formic acid (v/v); flow rate of $0.225 \mathrm{~mL} \mathrm{~min}^{-}$ ${ }^{1}$ and $10 \mu \mathrm{L}$ injection volume. A gradient elution mode [time (min),\% A, \%B] was used: [0.95, 5], [0.25, 95, 5], [7.75, 5, 95], [8.5, 5, 95 ], [8.51, 95, 5], [10, 95, 5], respectively (Kemmerich, 2017).

The calibration curves were prepared in the solvent and in the white extract of the matrix with adequate linearity and coefficient of determination values greater than 0.99 .

The limit of quantification (LOQ) and limit of detection (LOD) for water analysis with satisfactory precision, recovery between 70 and $110 \%$, and relative standard deviations below $19.7 \%$. For soil and sediment analyses, the recovery values were between 70 and $120 \%$, the relative standard deviations below $20 \%$. The limit of quantification (LOQ) and limit of detection (LOD) are described in the discussion 
section.

In each analysis, analytical quality control of the method was performed, who obtained different LOD and LOQ depending on the collection campaign and the active ingredient analyzed.

\section{Results and Discussion}

After analysis of sediment samples, all results found were below the limits of detection (LOD) and the limits of quantification (LOQ), thus considering that the active principles were not present in the sediment samples.

In the soil, only the active principles azoxystrobin and tricyclazole were found with values below the LOQ of the method, which was $0.008 \mu \mathrm{g} \cdot \mathrm{Kg}^{-1}$.

In campaigns $\mathrm{C} 2$ and $\mathrm{C} 3$, at points $\mathrm{P} 5$ and P4, azoxystrobin was found. Tricyclazole was found in $\mathrm{C} 3$ at $\mathrm{P} 4$ and P5, and in $\mathrm{C} 4$ at P5. At these points, there was no riparian forest protecting the Formoso riverbed, which may be one of the factors that led to contamination. For all active principles in soil analysis, the LOQ and LOD values of the method were $0.003 \mu \mathrm{g} . \mathrm{Kg}^{-1}$ and $0.008 \mu \mathrm{g} . \mathrm{Kg}^{-1}$, respectively, for all pesticides studied, except for methyl cremoxim, which had values of 0.010 and $0.033 \mu \mathrm{g} . \mathrm{Kg}^{-1}$, respectively, in $\mathrm{C} 2$.

All results found for the other active ingredients in soil collection campaigns were below these limits. There is no legislation in Brazil establishing levels of pesticide contamination in the soil. It cannot be established if the values found are allowed by the legislation (ALHO, 2005).

Some active ingredients were not detected in the water: imazamoxy, imazapic, imazapyr, imazaquin, cremoxim methyl, and piraclostrobina.

For all active principles in waters analysis, the LOQ and LOD values of the method were 0.006 $\mu \mathrm{g} . \mathrm{L}^{-1}$ and $0.020 \mu \mathrm{g} . \mathrm{L}^{-1}$, respectively, for all pesticides studied, except for methyl cremoxim, imazapir and imazamoxi, which had values of $0.012 \mu \mathrm{g} . \mathrm{L}^{-1}$ and $0.040 \mu \mathrm{g} . \mathrm{L}^{-1}$, respectively, in C2.

In $\mathrm{C} 1$, which was performed at the end of the region's rainy season, only tricyclasol was found from P4 to P7, with a value below the LOQ of the methods $\left(0.020 \mu \mathrm{g} . \mathrm{L}^{-1}\right)$, indicating that contamination arises in the river when it passes along the margin of the agricultural project.

The C3 was performed in the dry season in the region. In this campaign, at P1 and P2, a lower concentration than the LOQ of the method was found for fenamidone and azoxystrobin. The contamination by these active ingredients were already detected at P1 before the river passed along the agricultural project, indicating that contamination by these substances occurs even before its influence. By evaluating the results for these substances, we found that they dilute along the river and are no longer detected from P3.

At P5 and P6, tricyclazole and trifloxystrobin were found; at P7, tricyclazole had values lower than the LOQ. Contamination by these active principles arises within the agricultural project and continues until the river passes along it. Tricyclazole contamination remained in the C4 at P4, P5 and P7 (concentration lower than LOQ). In this campaign, it was quantified with a concentration of $0.022 \mu \mathrm{g} . \mathrm{L}^{-1}$ at P6. Contamination by these substances is constant in the Formoso River if we consider the region studied and arise within the agricultural project.

The imazethapyr was quantified in $\mathrm{C} 3$ at $\mathrm{P} 4$ with a concentration of $0.021 \mu \mathrm{g} . \mathrm{L}^{-1}$. After analyzing all data, the most critical points of contamination are from P4 because they are points where most of the 
active ingredients were found, both in water and on the riverbank soil, in most campaigns. The Formoso River, when passing the margin of the agricultural project, is being impacted by it.

After the study, the dry season in the region where the river is lower is the most critical period for threat to biodiversity.

In total, five active ingredients were found in water, namely tricyclazole, trifloxystrobin, imazethapyr, fenamidone and azoxystrobin.

Tricyclazole is currently one of the fungicides recommended for the treatment of diseases in irrigated rice. Wandscheer et al, (2017) indicates that the application of the tricyclazole fungicide leads to an increase in the genotoxic activity in the rice crop water, through the appearance of chromosomal abnormalities. This substance appears to have adversely effects on reproductive tissues and hormone levels (Fattahi, 2015).

Reimche at al. (2015) in study of the imazethapyr in zooplankton community, show that there is a selecrive impact on zooplankton community. Overall, the herbicide caused a rapid stimulation of cladocers, copepods and copepod (nauplius) population. On the other hand, rotifer population decreased, with recovery at the end of the experimental period.

All detected substances are authorized for use in Brazil. Tricyclazole and imazethapyr are not authorized in the European Union and are classified as with a medium to high toxicity. Despite the common occurrence of pesticide mixtures, legislation generally assesses the risk of a substance individually, but all compounds can contribute to the toxicity of the overall mixture even if they occur individually at concentrations that are not harmful to freshwater biota (Di Lorenzo et al., 2018).

While some active ingredients were not detected in the monitoring period and others were not found in all campaigns, this sporadic detection does not indicate that these substances are not contaminating the water body, as the detection of pesticides in natural environments (uncontrolled) is difficult because several dynamic processes are involved in these environments (dilution, dispersion, decomposition, hydrolysis, photolysis) (Calheiros et al., 2018).

The mobility and persistence of pesticides in the environment are related to water runoff intensity, rainfall and environmental temperature (Azevedo et al., 2016). The effects of dilution and low solubility of pesticides in water are responsible for their low concentration. However, after heavy rainfalls, high concentrations may occur when high doses have been applied (Dores and Lamonica, 2001).

Although pesticide residue concentrations are often low and within the values recommended by aquatic life and human safety legislation, there are two mechanisms of pesticide absorption within aquatic ecosystems, i.e., bioaccumulation and biomagnification, which increase their toxic potential (Upadhi and Wokoma, 2012). The effects of an active ingredient may also be potentiated in the presence of others synergistically. Studies on this and on the cumulative effects of pesticides are limited (Calheiros et al., 2018).

There are not many studies to compare with this work on the quantification of pesticides in different environmental compartments in the northern region of Brazil, more specifically in the Cerrado of Tocantins.

Guarda et al. (2020a, 2020b, 2020c), detect the presence of pesticides of the class of carbamates, environmental, of the different classes of carbamates, benzimidazoles, among others in the region, therefore, studies in the state are numerous. 
The availability of existing information is greater for other regions, although still scarce. They report on places with biomes different from those of this study. The lack of information on quantitative data can be justified by the fact that there is no analytical infrastructure in the state of Tocantins to determine the levels of these substances, in addition to the logistics for sending samples to other regions. This is a difficulty for studies conducted in Tocantins.

\section{Conclusion}

Thus, according to the results, it is evident that the threat to the biodiversity of the Tocantins Cerrado is increasing every day. This is because, after the study, two contaminated environmental compartments (soil and water) were found, with five substances of medium to high toxicological classes.

The degradation of the Cerrado biome is threatened by the agricultural expansion of the studied region. This concern increases as indigenous peoples who live in the region and feed on the resources of this river may be exposed to these substances.

\section{Declarations}

\section{Funding}

The present work was carried out with the support of the Coordination of Improvement of Higher Education Personnel Brazil - (CAPES) - Financing Code [001].

\section{Competing interests}

The authors have no relevant financial or non-financial interest in disclosing

\section{Author Contributions}

All authors read and approved the final manuscript. PMG, main author of the article, participated in all stages, from planning to final writing of the text. LSG helped in sample collection and preparation for analysis. DBM helped in writing and formatting the article and translating the text into

English. EAG, and JEC da S were co-supervisor and supervisor, respectively, supervising all experimental and theoretical work and reviewing the article.

\section{Data Availability}

The datasets used and/or analysed during the current study are available from the corresponding author on reasonable request.

The datesets generated during and/or analysed during the current study are available in the Environmental impact assessment of an agricultural project in the region of Formoso do Araguaia, on the quality and biodiversity of the Rio Formoso. 2020. 236f. Thesis (Doctorate in Biotechnology and Biodiversity) Federal University of Tocantins, Postgraduate Program in Biodiversity and Biotechnology Rede Bionorte, Palmas, 2020. Available at: http://hdl.handle.net/11612/2185 


\section{References}

ABURJAIle, S. B.; SILVA, M. P.; BATISTA, E. A. F. S.; BARBOSA, L. P. J. L.; BARBOSA, F. H. F (2011) Search and characterization of diversity microbiological soil in the Area of São José do Buriti - MG, as a result of replacement native forest cover (savanna) in eucalyptus plantations. Ciência Equatorial, v. 1, n. 2 .

ALHO, C.J.R. (2005) Desafios para a conservação do Cerrado, em face das atuais tendências de uso e ocupação. In: SCARIOT, A.; SOUSA-SILVA, J.C.; FELFILI, J.M. (Org.). Cerrado: ecologia, biodiversidade e conservação. Brasília: Ministério do Meio Ambiente, p. 367-381.

AZEVEDO, J. C. R.; MOURA, E. R. R.; SANTOS, M. M. (2016) Determination of pesticides in Piquiri River water and sediment Rama: Revista em Agronegócio e Meio Ambiente, v 9, n 3, p 651- 671. jul/set. DOI:http://dx.doi.org/10.17765/2176-9168.2016v9n3p651-671

CAlHEIROS, D. F.; PIGNATI, W. A., PINHO, A. P.; SOUZA E LIMA, F. A. N.; SANTOS, J.; PINHO, J. S.; ROSA, E. R., Relatório Técnico Projeto: Promoção da Agroecologia e Avaliação da Contaminação por Agrotóxicos em Áreas de Proteção Ambiental na Bacia do Alto Paraguai - APA Estadual Nascentes do Rio Paraguai-Ministério da Educação, Universidade Federal de Mato Grosso -Instituto de Saúde Coletiva/Departamento de Saúde Coletiva Núcleo de Estudos Ambientais e Saúde do Trabalhador, 2018. Available in: http://ecoa.org.br/wp-content/uploads/2018/05/988025221b5fb8dd47b50334964de19e.pdf Accessed in 16 april 2019.

CARVALHO, J. J.; LUZ, J. M. R.; HENRIQUE, J.; SILVA, J. G. D.; FERNANDES, R. B. A.; RIBEIRO, S. S.; SILVA, J. E. C. (2018). Biofertigations of forage wilh effluents from a cattle slawghterhouse green line: impacts on physical chemical indicators of soil quality and on production biomass. Journal of Agricutural Science. v. 10, n. 7, p. 359-382. . DOI: 10.5539/jas.v10n7p359

CETESB- Guia nacional de coleta e preservação de amostras: água, sedimento, comunidades aquáticas e efluentes líquidos / Companhia Ambiental do Estado de São Paulo; Organizadores: Carlos Jesus Brandão ... [et al.]. -- São Paulo: CETESB; Brasília: ANA, 2011.

DE GERÓNIMO, E.; APARICIO, V. C., BÁRBARO, S.; PORTOCARRERO, R.; JAIME, S.; COSTA, J. L. (2014). Presence of pesticides in surface water from four sub-basins in Argentina. Chemosphere, v.107, p.423-431. https://doi.org/10.1016/j.chemosphere.2014.01.039

DI LORENZO, T.; CIFONI, M.; FIASCA, B.; DI CIOCCIO, A.; GALASSI, D. M. P. (2018). Ecological risk assessment of pesticidemixtures in the alluvial aquifers of central Italy: Toward more realistic scenarios for risk mitigation Science of the Total Environment v. 644 p. 161-172. DOI: https://doi.org/10.1016/j.scitotenv.2018.06.345 
DONATO, F. F.; MARTINS, M. L.; MUNARETTO, J. S.; PRESTES, O. D.; ADAIME, M. B.; ZANELLA, R. (2015) Development of a Multiresidue Method for Pesticide Analysis in Drinking Water by Solid Phase Extraction and Determination by Gas and Liquid Chromatography with Triple Quadrupole Tandem Mass Spectrometry. JBCS, v. 26, n. 10, p. 2077-2087. http://dx.doi.org/10.5935/0103$\underline{5053.20150192}$

DORES, E. F. G. C.; LAMONICA-FREIRE, E. M. (2001). Contamination of the aquatic environment by pesticides. Case study: Waters used for human consumption in Primavera do Leste, Mato Grosso Preliminary analysis. Química Nova, v.24, p. 27-36. http://dx.doi.org/10.1590/S0100$\underline{40422001000100007}$

FATTAHI, E., MOGHADDAM, M.; KHANBABAEI, R.A.; (2015) The Effect of Tricyclazole on Testosterone Changes and Testicular Structure in Mice. Journal of Babol University of Medical Sciences. V.16, p. 43-49.

FILIZOLA, E. F.; GOMES, M. A. F. SOUZA, M.D., Manual de procedimentos de coleta de amostras em áreas agrícolas para análise da qualidade ambiental: solo, água e sedimentos. Jaguariúna: Embrapa Meio Ambiente, 2016.

GUARDA, P. M., PONTES, A. M. S., DOMICIANO, R. S.;GUALBERTO, L. S.; MENDES, D. B.; GUARDA, E. A.; SILVA, J. E. C.. Assessment of Ecological Risk and Environmental Behavior of Pesticides in Environmental Compartments of the Formoso River in Tocantins, Brazil. Arch Environ Contam. Toxicol, v.79, p.524-536, 2020. DOI: http://doi.org/10.1007/ s00244-020-00770-7

GUARDA, P. M., PONTES, A. M. S., DOMICIANO, R. S.; GUALBERTO, L. S.; MENDES, D. B.; GUARDA, E. A.; SILVA, J. E.C. Analysis of triazines, triazoles, and benzimidazoles used as pesticides in different environmental compartments of the Formoso River and their influence on biodiversity in Tocantins. Journal of Environmental Science and Health, Part B, v.55, n.9, p.783-793, 2020. DOI: http://doi.org/10.1080/03601234.2020.1784667

GUARDA, P. M., PONTES, A. M. S., DOMICIANO, R. S.; GUALBERTO, L. S.; MENDES, D. B.; GUARDA, E. A.; SILVA, J. E. C.. Determination of Carbamates and Thiocarbamates inWater, Soil and Sediment of the Formoso River, TO, Brazil . Chemistry \& Biodiversity, v.17, n.4, 2020. DOI: https://doi.org/10.1002/cbdv.201900717

ISHERWOOD, K. F. Mineral Fertilizer use ande the environment - International Fertilizes Industry Association. Revised Edition. Paris. February, 2000. 
KEMMERICH, M. Pesticide residues in plum, apple, pear and peach: development of analysis and monitoring methods. 2017. 140f. PhD thesis in Chemistry, Federal University of Santa Maria, Santa Maria, 2017.

KUSSUMI, T. A. Development of a multiresidue method for the determination of benzimidazolic pesticides, carbamates and triazines in corn by Liquid Chromatography coupled to tandem Mass Spectrometry and its certification. 2007. 150f. Dissertation (Master of Science in the area of Nuclear Materials Technology) Institute for Energy and Nuclear Research, São Paulo, 2007.

MAGAlHAES, L. Biomas Brasileiros. Toda Matéria, 2018. Available in: https://www.suapesquisa.com/meio_ambiente/mapa_biomas_brasil.htm. Acessed in 27 march 2019.

MATTOS, M. L. B.; MATTOS, P. H. C.; CARNiEllo, M. F.; ARAUJO, E. A. S. (2013) Javaé native people from the Bananal Island: an analysis about development of those communities. Revista Cereus. v. 5., n. 3, p. 101-116.

MESQUITA, V. A. Characterization of the microbiological diversity of soils in the Cerrado of Minas Gerais by denaturing gradient gel electrophoresis (DGGE).2011. 71f. Dissertation (Master in Agricultural Microbiology), Federal University of Lavras, Lavras, 2011.

MONTEIRO, G. G. Analysis of the fungi community in Amazonian soils by gel electrophoresis with denaturing gradient (DGGE).2007. 48f. Dissertation (Master in Agricultural Microbiology), Federal University of Lavras, Lavras, 2007.

OLIVEIRA, A.; SILVA, N. (2013) Determination of the concentration of metals in waters of the Barbado Stream, Cuiabá - MT. R. Gest. Sust. Ambient., Florianópolis, v. 2, n.1, p. 47-63, abr./set. http://dx.doi.org/10.19177/rgsa.v2e1201347-63

PRESTES, O.D.; FRIGGI, C.A.; ADAIME, M. B.; ZANELLA, R. (2009) QuEChERS - A modern sample preparation method for pesticide multiresidue determination in food by chromatographic methods coupled to mass spectrometry. Química Nova, v. 32, n. 6, p. 1620-1634. DOI: http://dx.doi.org/10.1590/S010040422009000600046

RAND, G.M.; PETROCELLI, S.R. Fundamentals of aquatic toxicology: methods and application. Washington, USA: Hemisphere Publishing, 1985. 666p.

REIMCHE, G.B.; MACHADO, S.L.O; OLIVEIRA, M.A.; ZANELLA, R.; DRESSLER, V.L.; FLORES, E.M.M; GONÇALVES, F.F.; DONATO, F.F.; NUNES, M.A.G; (2015) Imazethapyr and imazapic, bispyribac-sodium and penoxsulam: Zooplankton and dissipation in subtropical rice paddy water. The Science of the Total Environment, v.514, p. 68-76 
SEMARH- Secretaria do Meio Ambiente e Recurso Hídricos- Governo do Tocantins. Boletim de qualidade de água- Boletim 2017. Available at: https://semarh.to.gov.br/diretorias/diretoria-de-planejamento-erecursos-hidricos/boletim-de-qualidade-de-agua/-boletim-anual-2017-/. Accessed 01 may 2019.

SEMARH- Secretaria do Meio Ambiente e Recurso Hídricos- Governo do Tocantins. Boletim de qualidade de água- Boletim Trimestral 1/2018a. Available at: ;https://central3.to.gov.br/arquivo/416996/. Accessed 01 de may 2019.

SEMARH- Secretaria do Meio Ambiente e Recurso Hídricos- Governo do Tocantins. Boletim de qualidade de água- Boletim Trimestral 2/2018b. Available at:: https://central3.to.gov.br/arquivo/412019/. Accessed 01 de may 2019.

SEMARH- Secretaria do Meio Ambiente e Recurso Hídricos- Governo do Tocantins. Boletim de qualidade de água- Boletim Trimestral 3/2018c. Available at:: https://central3.to.gov.br/arquivo/416998/. Accessed 01 de may 2019.

SEMARH- Secretaria do Meio Ambiente e Recurso Hídricos- Governo do Tocantins. Boletim de qualidade de água- Boletim Trimestral 4/2018d. Available at: https://central3.to.gov.br/arquivo/427447/. Accessed 01 de may 2019.

SEPLAN- Secretaria do Planejamento e Orçamento - Governo do Estado do Tocantins- Perfil Do Agronegócio Tocantinense-Versão Final (P6). Março 2016

SEPLAN- Secretaria do Planejamento e Orçamento - Governo do Estado do Tocantins- Base de Dados Geográficos do Estado do Tocantins- 2012, Available in: http://www.sefaz.to.gov.br/zoneamento/basesvetoriais/base-de-dados-geograficos-do-tocantins-atualizacao-2012/ Acessed 28 may 2019.

SILVA, M., R. S. S. Diversity of bacterial communities of Cerrado soils in response to different changes in ecosystems, 2012. 154f. Thesis (Doctorate in Ecology). Institute of Biological Sciences, Department of Ecology, Federal University of Brasília, Brasília, 2012.

UPADHI, F; WOKOMA, O.A.F. (2012) Examination of Some Pesticide Residues in Surface Water, Sediment and Fish Tissue of Elechi Creek, Niger Delta, Nigeria Research Journal of Environmental and Earth Sciences n. 4, v. 11, p. 939-944.

ZHANG, M.; LIANG, Y.; SONG, A.; YU, B.; ZENG, X.; CHEN, M.; YIN, H.; ZHANG, X.; SUN, B.; FAN. F. (2017) Loss of soil microbial diversity may increase insecticide uptake by crop. Agriculture, Ecosystems and Environment. v. 204, p. 84-91. https://doi.org/10.1016/j.agee.2017.02.010 
WANDSCHEER. A.C.D.; MARCHESAN, E.; DA SILVA, M.F.; ARAMBURU, B.B.; DE DAVID. R.; TRIVISIOL, V.S.; DA SILVA, A.L.; (2017) Impact of fungicide and insecticide use on non-target aquatic organisms in rice paddy fields. Ciência Rural, Santa Maria, v.47, n 01. 